\title{
Hydrogeochemical assessment of groundwater in Kashmir Valley, India
}

\author{
G H Jeelani*, Rouf Ahmad Shah and Aadil Hussain \\ Department of Earth Sciences, University of Kashmir, Srinagar, J $\& 3$ K 190 006, India. \\ ${ }^{*}$ Corresponding author. e-mail: geojeelani@gmail.com
}

Groundwater samples $(n=163)$ were collected across Kashmir Valley in 2010 to assess the hydrogeochemistry of the groundwater in shallow and deep aquifers and its suitability for domestic, agriculture, horticulture, and livestock purposes. The groundwater is generally alkaline in nature. The electrical conductivity (EC) which is an index to represent the total concentration of soluble salts in water was used to measure the salinity hazard to crops as it reflects the TDS in groundwater ranging from 97 to $1385 \mu \mathrm{S} / \mathrm{cm}$, except one well in Sopore. The average concentration of major ions was higher in shallow aquifers than in deeper aquifers. In general, $\mathrm{Ca}^{2+}$ is the dominant cation and $\mathrm{HCO}_{3}^{-}$the dominant anion. $\mathrm{Ca}-\mathrm{HCO}_{3}, \mathrm{Mg}-\mathrm{HCO}_{3}, \mathrm{Ca}-\mathrm{Mg}-\mathrm{HCO}_{3}, \mathrm{Na}-\mathrm{HCO}_{3}$ were the dominant hydrogeochemical facies. High concentration of $\mathrm{HCO}_{3}$ and $\mathrm{pH}$ less than 8.8 clearly indicated that intense chemical weathering processes have taken place in the study area. The groundwater flow pattern in the area follows the local surface topography which not only modifies the hydrogeochemical facies but also controls their distribution. The groundwater in valley flows into four directions, i.e., SW-NE, NE-W, SE-NW and SE-NE directions. The results suggest that carbonate dissolution is the dominant source of major ions followed by silicate weathering and ion-exchange processes. The concentrations of all the major ions determined in the present study are within the permissible limits of WHO and BIS standards. The results of Total Hardness, SAR, Na\%, Kelly Index, USDA classification, Magnesium absorption ratio, residual sodium carbonate, and PI suggested that groundwater is good for drinking, livestock, and irrigation purposes.

\section{Introduction}

Groundwater, being the largest freshwater resource after glaciers and polar ice in the world, plays an important role in socio-economic life of the people in Kashmir Valley for domestic, horticultural, agricultural, and hydropower generation purposes. The suitability of groundwater for different purposes depends upon its intrinsic quality which reflects inputs from the atmosphere, soil and rock weathering, as well as from anthropogenic activities. Public ignorance of environment and related considerations, indiscriminate disposal of increasing anthropogenic wastes, unplanned application of agrochemicals, and discharges of improperly treated sewage have resulted in the deterioration of surface and subsurface water (Singh and Hasnain 1998; Mitra et al. 2007; Kumar et al. 2008; Ishaku 2011; Ewusi et al. 2013; Kalpana and Elango 2013). The value of groundwater lies not only in its widespread occurrence and availability but also in its consistent good quality (Rajmohan et al. 2000; UNESCO 2000). Assessment of water quality is very important for knowing the suitability for various purposes

Keywords. Hydrochemistry; carbonate weathering; silicate weathering; Kashmir Valley. 
(Ifatimehin and Musa 2008; Jehangir et al. 2011). Hydrogeochemical study is a useful tool in understanding and identifying the processes that are responsible for chemical quality of groundwater (Subba Rao 2008; Kumar et al. 2013). Very few hydrogeochemical studies have been carried out in Kashmir Valley. Jeelani $(2005,2011)$ carried out the study on the chemical quality of springs southeast of the Kashmir Valley and suggested that congruent carbonate dissolution (calcite dissolution, dedolomitization) and incongruent silicate weathering were found to be the dominant processes controlling the groundwater chemistry. Jehangir et al. (2011) also carried out hydrogeochemistry of groundwater along river Jhelum in the southern part of Kashmir and suggested lithology as a dominant factor in controlling the water chemistry. However, a comprehensive study on hydrogeochemistry of whole alluvial basin is lacking till date. The present study is focussed on the general hydrogeochemistry of the groundwater in alluvial wells of the Kashmir Valley because of its unique aspects of hydrogeology and its relative importance of hydrogeology to this large part of valley, which is although preliminary in nature but gives a first hand idea about the chemical quality of the groundwater.

\section{Study area}

The intermountane valley of Kashmir formed by bifurcation of the great Himalayan range west of Ravi, occupies an oval shaped depression between two major orogenic axis of upheaval namely, folded Pir Panjal range to the southwest and much sheared ranges of north Kashmir to the northeast located between latitudes $32^{\circ} 17^{\prime}$ and $36^{\circ} 58^{\prime} \mathrm{N}$ and longitudes $73^{\circ} 26^{\prime}$ and $80^{\circ} 30^{\prime} \mathrm{E}$, possessing almost a complete stratigraphic record of rocks of all ages (figure 1) ranging from Archean to Recent (Middlemiss 1910, 1910; Wadia 1975; GSI 1977; Gunj and Khar 1984). The average length of Kashmir Basin is $140 \mathrm{~km}$ and width $40 \mathrm{~km}$, covering an area of $5200 \mathrm{~km}^{2}$, with an average elevation of $1850 \mathrm{~m}$ (amsl) (Agarwal et al. 1979). The central part of the valley, mostly covers the flood plains of the river Jhelum and adjoining streams, and is filled with recent alluvium. These deposits include alluvial tracts, flood plains, river terraces and talus and scree fans. The alluvial flats of the valley are bordered by the Karewa deposits whose denuded tops offer sharp contrast to the aggradational features of the low lying tracts (Jeelani 2007). The valley enjoys a temperate climate with marked seasonality. The valley experiences the highest rainfall of $275 \mathrm{~mm}$ in summer and the lowest $50 \mathrm{~mm}$ in winter with a mean annual rainfall of $100 \mathrm{~mm}$. The mean annual temperature of the valley is $19^{\circ} \mathrm{C}$. The valley is mainly drained by river Jhelum.

\section{Materials and methods}

A total of 163 groundwater samples (104 from shallow groundwater $=$ SGW and 59 samples from deep groundwater $=\mathrm{DGW}$ ) were collected across the alluvial aquifer/s of Kashmir Valley during 2010 (figure 1). These wells were selected not only after a proper well inventory survey across the whole alluvial basin but also on the basis of demographic need and were classified on the basis of spatial variation in depth to water table from southern, central, and northern parts of the alluvial basin of the valley. The depths to water table in these alluvial wells were measured with a hand-held sensor capable of accuracy to about 0.1 inch, whereas data were recorded on a datalogger, which later was analysed in the ARC GIS 9.3 software by interpolating 163 data points by using Universal Kriging (UK) method with an exponential semi-variogram model, which is considered one of the most appropriate interpolation methods for contouring groundwater level, generally a non-stationary variable (Gundogdu and Guney 2007). The depths to water table in the range of $0-2 \mathrm{~m}$ were classified as shallow alluvial wells, whereas from $2 \mathrm{~m}$ or more were classified as deep alluvial wells. The water samples taken from these wells were filtered through $<0.45 \mu \mathrm{m}$ neucleopore membrane and collected in $500 \mathrm{ml}$ HDPE bottles and were analysed for chemical parameters in the Hydrogeology Laboratory of the Department of Earth Sciences, University of Kashmir. The standard methods were adopted to analyse the dissolved chemical constituents (APHA, AWWA and WEF 2001). The in situ parameters including temperature, $\mathrm{pH}$, electrical conductivity (EC) and alkalinity were measured at site. Total dissolved solids were estimated by calculating total cations and total anions ( $\mathrm{TZ}$ concentration). Alkalinity was measured by $\mathrm{HCl}$ titration; $\mathrm{Ca}^{2+}$ and $\mathrm{Mg}^{2+}$ by EDTA titration; $\mathrm{Cl}^{-}$ by $\mathrm{AgNO}_{3}$ titration; $\mathrm{SO}_{4}^{-}, \mathrm{NO}_{3}^{-}, \mathrm{Fe}^{2+}$ and $\mathrm{F}^{-}$by spectrophotometer; $\mathrm{Na}^{+}$and $\mathrm{K}^{+}$by flame emission photometry. During the analytical procedures, blanks and standards were run to check the reliability of the methods adopted. In most of the water samples, the total cation charge $\left(\mathrm{TZ}^{+}=\mathrm{Ca}^{2+}+\right.$ $\mathrm{Mg}^{2+}+\mathrm{Na}^{+}+\mathrm{K}^{+}+\mathrm{Fe}^{2+}$ in meq/L) balances that of the total anions $\left(\mathrm{TZ}^{-}=\mathrm{HCO}_{3}^{-}+\mathrm{Cl}^{-}+\mathrm{SO}_{4}^{-}+\right.$ $\mathrm{NO}_{3}^{-}+\mathrm{F}^{-}$in meq/L) within analytical uncertainties and the normalized inorganic charge balance $\left.\left(\mathrm{NICB}=\mathrm{TZ}^{+}-\mathrm{TZ}^{-}\right) / \mathrm{TZ}^{+} \times 100 \%\right)$ is found to be within $\pm 5 \%$. 


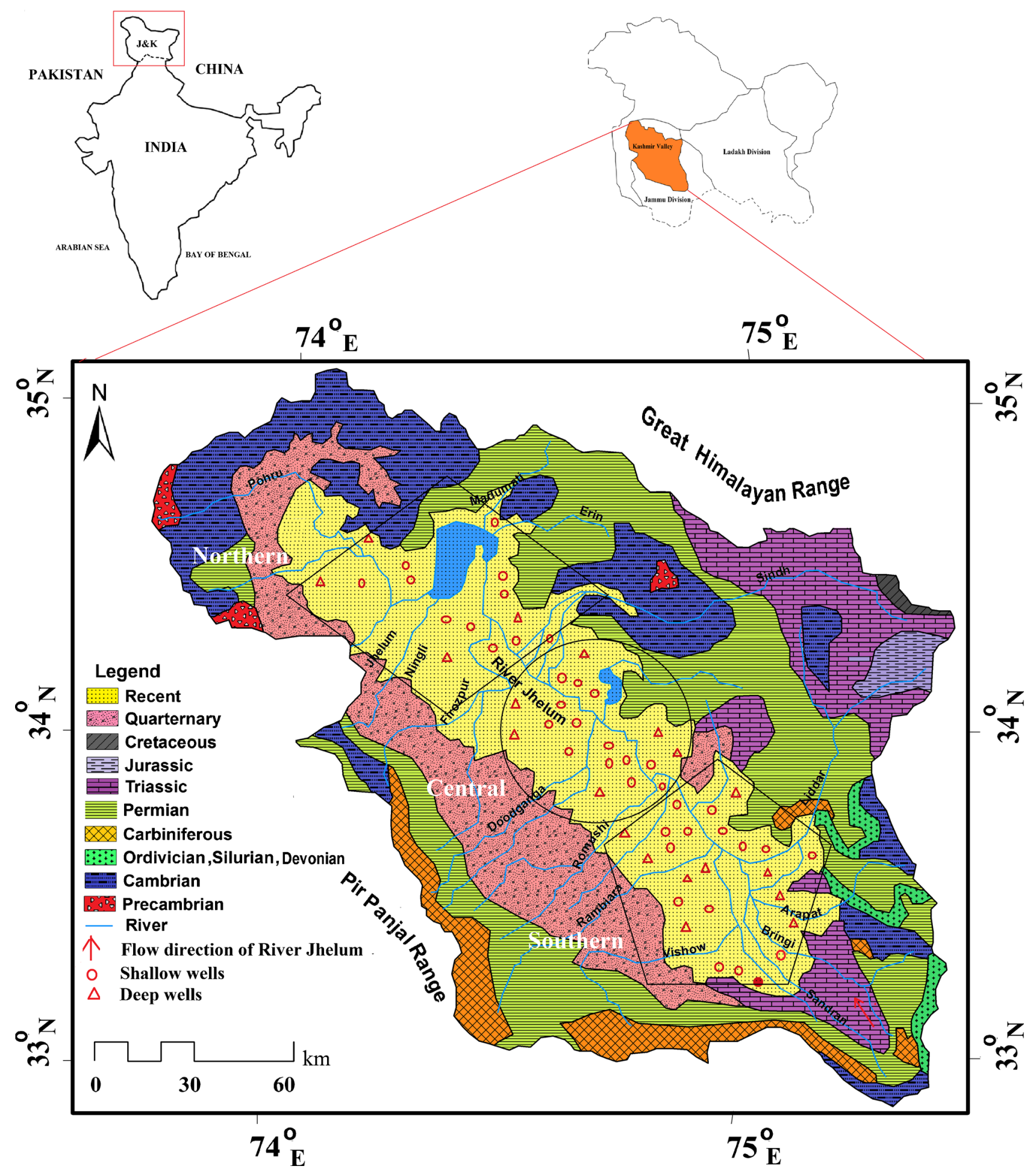

Figure 1. Geology of the study area and the location of sampling sites.

\section{Results and discussion}

\subsection{Hydrochemistry: Spatial variation}

The summary of the physico-chemical parameters generated from the analysis of the 163 samples were presented in table 1 . The data was compared with drinking water guidelines of India (BIS-IS
10500:1991) and WHO (2006). The groundwater samples were mostly alkaline $(\mathrm{pH}: 6.7-8.8)$ with the exception of a few samples from Kangan, Srikaningund, Ajas and Babgund (pH: 6.7 and 6.9 ). The shallow groundwater samples were more alkaline (average $\mathrm{pH}: 7.6$ ) than deep groundwater samples (average pH: 7.4). Electrical conductivity (EC) which is an index to represent the total 


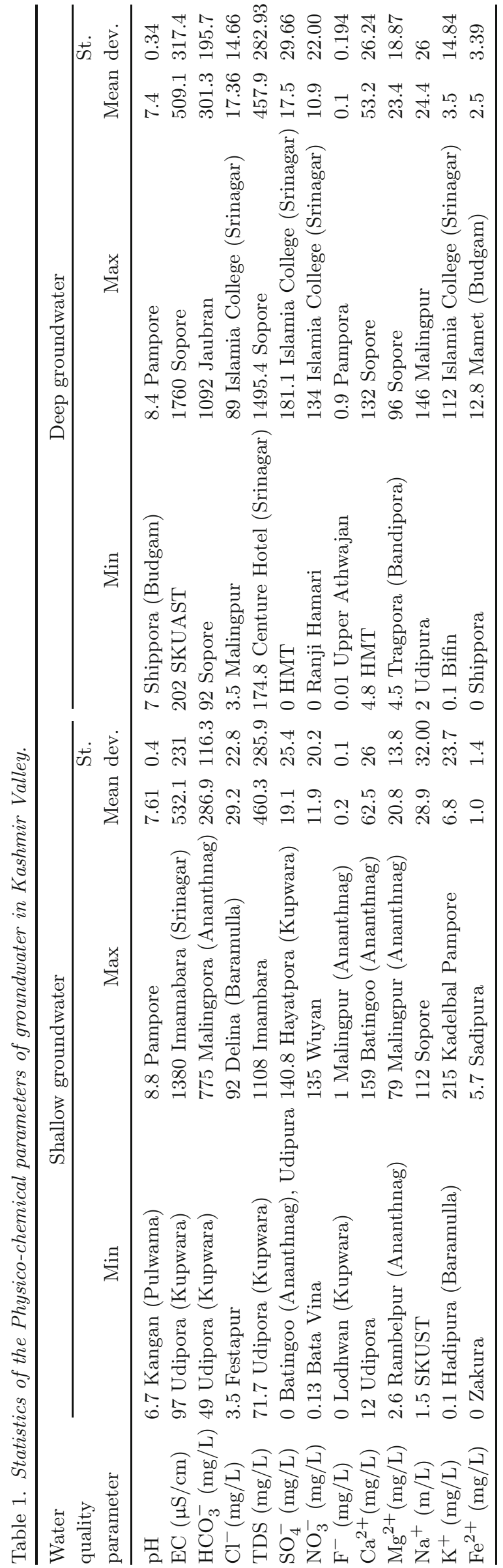

concentration of soluble salts in water varied from 97 to $1385 \mu \mathrm{S} / \mathrm{cm}$ except at one well in Sopore $(1760 \mu \mathrm{S} / \mathrm{cm})$, with an average of $523.7 \mu \mathrm{S} / \mathrm{cm}$. EC is mostly higher in shallow groundwater (average $\mathrm{EC}=532.1 \mu \mathrm{S} / \mathrm{cm}$ ) than in deep groundwater (average $\mathrm{EC}=509.1 \mu \mathrm{S} / \mathrm{cm}$ ). The higher values of EC may be due to the long residence time and the existing lithology of the region. Total dissolved solids (TDS), which is a general indicator of water quality generally used to understand the amount of contaminant present in the groundwater (Bhardwaj and Singh 2011; Kumar et al. 2013), which was calculated by multiplying the EC with 0.64 , ranged from 71.7 to $1495.4 \mathrm{mg} / \mathrm{L}$ with an average of $459.4 \mathrm{mg} / \mathrm{L}$, being higher in shallow groundwater (average $=460.3 \mathrm{mg} / \mathrm{L}$ ) and lower in deep groundwater (average $=457.9 \mathrm{mg} / \mathrm{L}$ ).

Among the cations $\left(\mathrm{TZ}^{+}\right)$the concentration of $\mathrm{Ca}^{2+}$, essential for bones and teeth varied from 12 to $159 \mathrm{mg} / \mathrm{L}$ with an average of $59.2 \mathrm{mg} / \mathrm{L}$, being higher in shallow groundwater (average $\left.\mathrm{Ca}^{2+}=62.5 \mathrm{mg} / \mathrm{L}\right)$ than in deep groundwater (average $\mathrm{Ca}^{2+}=53.2 \mathrm{mg} / \mathrm{L}$ ). The concentration of $\mathrm{Mg}^{2+}$, essential element for membrane structure ranged from 2.6 to $96 \mathrm{mg} / \mathrm{L}$ with an average of $21.8 \mathrm{mg} / \mathrm{L}$. The deep groundwater was more enriched in $\mathrm{Mg}^{2+}\left(\right.$ average $\left.\mathrm{Mg}^{2+}=23.4 \mathrm{mg} / \mathrm{L}\right)$ than shallow groundwater (average $\mathrm{Mg}^{2+}=20.8 \mathrm{mg} / \mathrm{L}$ ). The $\mathrm{Na}^{+}$concentration, essential for controlling of fluid level and nerve conduction ranged from 1.5 to $146 \mathrm{mg} / \mathrm{L}$ with an average of $26.1 \mathrm{mg} / \mathrm{L}$ being high (average $\mathrm{Na}^{+}=28.9 \mathrm{mg} / \mathrm{L}$ ) in shallow groundwater and low (average $\mathrm{Na}^{+}=24.4 \mathrm{mg} / \mathrm{L}$ ) in deep groundwater. The $\mathrm{K}^{+}$, necessary in muscle contraction varied from 0.1 to $215 \mathrm{mg} / \mathrm{L}$ with an average of $5.7 \mathrm{mg} / \mathrm{L}$, higher (average $\mathrm{K}^{+}=6.89 \mathrm{mg} / \mathrm{L}$ ) in shallow groundwater as compared to deep groundwater (average $\mathrm{K}^{+}=3.59 \mathrm{mg} / \mathrm{L}$ ).

Among the major anions $\left(\mathrm{TZ}^{-}\right)$the concentration of $\mathrm{HCO}_{3}^{-}$, although having no adverse effects but preferably within the permissible limits (BIS 1991; Bhalme and Nagarnaik 2012), ranged from 49 to $1092 \mathrm{mg} / \mathrm{L}$ with an average of $292.2 \mathrm{mg} / \mathrm{L}$. The deep groundwater being more enriched (average $\mathrm{HCO}_{3}^{-}=301.3 \mathrm{mg} / \mathrm{L}$ ) than shallow groundwater (average $\mathrm{HCO}_{3}^{-}=286.9 \mathrm{mg} / \mathrm{L}$ ). Similarly, the concentration of $\mathrm{Cl}^{-}$, essential for metabolism ranged from 3.5 to $92 \mathrm{mg} / \mathrm{L}$ with an average of $25 \mathrm{mg} / \mathrm{L}$ with higher concentration (average $\mathrm{Cl}^{-}=29.2 \mathrm{mg} / \mathrm{L}$ ) in shallow ground water and lower (average $\mathrm{Cl}^{-}=17.3 \mathrm{mg} / \mathrm{L}$ ) in deep ground water. The concentration of $\mathrm{SO}_{4}^{-}$, essential for many biological processes like in the formation of brain tissue and Mucin proteins in gut walls (Kuchel et al. 1986; Dawson 2013), ranged from 0 to $181 \mathrm{mg} / \mathrm{L}$ with an average of $18.5 \mathrm{mg} / \mathrm{L}$, being higher (average $\mathrm{SO}_{4}^{-}=19.1 \mathrm{mg} / \mathrm{L}$ ) in shallow groundwater than deep groundwater (average 
$\left.\mathrm{SO}_{4}^{-}=17.5 \mathrm{mg} / \mathrm{L}\right)$. Nitrate concentration, which is an index of anthropogenic activities, varied from 0.13 to $135 \mathrm{mg} / \mathrm{L}$ with an average of $11.33 \mathrm{mg} / \mathrm{L}$. The higher concentration (average $\mathrm{NO}_{3}^{-}=$ $11.9 \mathrm{mg} / \mathrm{L}$ ) was observed in shallow groundwater than in the deep groundwater (average $\mathrm{NO}_{3}^{-}=$ $10.9 \mathrm{mg} / \mathrm{L}$ ). The spatial variation maps (figure 2) clearly indicate that recharge areas feeding these alluvial wells are in carbonates (limestone), silicates (Panjal Trap and Karewa) which surround the basin. These spatial variation maps also depict completely that rock-water interaction, velocity and quantity of groundwater flow, nature of geochemical reactions, and anthropogenic activities are the processes that have played a major role in the spatial variation of these major ions in the groundwater in the study area.

\subsection{Sources of major ions in groundwater}

Groundwater chemistry in the study region is regulated by diverse processes and mechanisms. Experiencing subtropical climatic condition, besides rock-water interaction, precipitation and evaporation may also contribute to the groundwater chemistry. The Gibbs mechanisms (Gibbs 1970) were employed in the study area suggesting that groundwater chemistry in the region has been controlled by the chemical weathering of rock forming minerals existing mainly in the volcanics, carbonates and Karewa, as weathering and ion exchange processes are the major solute acquisition mechanisms controlling the concentration of chemical constituents in groundwater besides the inputs from anthropogenic sources (Apodaca et al. 2002; Martinez and Bocanegra 2002; Singh and Hasnain 2002; Jeelani and Shah 2006; Bhardwaj et al. 2010; Li et al. 2010).

It was observed that most of the major ions were high in shallow groundwater aquifers except $\mathrm{Mg}$, $\mathrm{HCO}_{3}$ and Fe. The sources of major ions in shallow groundwater may be attributed to lithogenic and anthropogenic activities. It is important to mention here that the shallow groundwater is more prone and vulnerable to contamination. In the study area, the unmanaged and untreated sewage and water logging is widespread. The lower concentration of major ions in the deeper aquifer indicates that the source of major ions is lithogenic in deeper aquifers, which are naturally more protected from contamination by anthropogenic activities. However the higher concentration of $\mathrm{Mg}, \mathrm{HCO}_{3}$ and $\mathrm{Fe}$ in the deeper aquifer may be due to interaction of water with dolomite and/or ferro-magnesium minerals of Panjal Trap. This is also supported by the plot $\mathrm{Mg}$ vs. $\mathrm{HCO}_{3}$ (figure 3d). The plot $\mathrm{Mg}$ vs. $\mathrm{HCO}_{3}$ shows a good correlation in deeper aquifers than in shallow aquifers, suggesting that dolomite and/or Panjal Trap is a source. However, the relative proportion of various dissolved ions in the groundwater depends on their abundance in the host rock/aquifers and its solubility (Sarin et al. 1989). The present study has been carried out in the alluvial tract (host lithology) of the valley, surrounded on NE side by Triassic Limestone and Panjal Trap, which is rich in ferromagnesium minerals and on SW side by carbonates, sulphides/evaporites and quarternary Karewa Group of sediments. The ion exchange between the ground water and its host environment during residence or during in movement process can be best understood by chlorine alkaline indices also known as Scholler index (Schoeller 1977) expressed as: $\mathrm{CAI}=\mathrm{Cl}^{-}-\mathrm{Na}^{+}+\mathrm{K}^{+} / \mathrm{Cl}^{-}$. A majority of the samples from shallow groundwater $(62 \%)$ showed positive CAI indicating base exchange reaction, whereas $38 \%$ of samples showed negative CAI indicating cation-anion exchange reaction. In the case of deep groundwater, most of the samples (58\%) showed negative CAI indicating the dominance of cation-anion exchange reaction whereas $42 \%$ samples showed positive CAI indicating base exchange reaction. However, the sources of these dissolved constituents can be best evaluated from the relative abundance of individual ions and their inter-elemental correlation. The plots of $\mathrm{Ca}+\mathrm{Mg}$ vs. $\mathrm{HCO}_{3}$, $\mathrm{Na}$ vs. $\mathrm{Cl}$, and $\mathrm{Ca}+\mathrm{Mg}$ vs. $\mathrm{HCO}_{3}+\mathrm{SO}_{4}$ scatter diagrams (figure 3) helped to determine the possible sources of major ions in groundwater. In $\mathrm{Ca}+\mathrm{Mg}$ vs. $\mathrm{HCO}_{3}$ plot, most samples fall along the line, although some of the samples fall below the line suggesting possible contribution from the carbonate lithology besides some contribution from other processes. The plot of $\mathrm{Na}$ vs. $\mathrm{Cl}$ showed that most points lie below the aquiline indicating the contribution from silicates, because $\mathrm{Cl}$ would prefer to associate with alkalies than alkaline earth elements. This phenomena was also noticed when $\mathrm{Na} / \mathrm{Cl}$ ratio is greater than 1 which indicates that sodium is released from silicate weathering (Meybeck 1987). Hence in the present study about $51 \%$ and $72.88 \%$ samples from shallow and deep ground waters, respectively have $\mathrm{Na} / \mathrm{Cl}$ ratio $>1$, means $\mathrm{Na}$ has come from silicate weathering. The remaining $49 \%$ from shallow and $27.12 \%$ samples from deep ground water have $\mathrm{Na} / \mathrm{Cl}$ ratio $<1$ reflecting impact or presence of additional source. This is also evident in $\mathrm{Ca}+\mathrm{Mg}$ vs. $\mathrm{HCO}_{3}+\mathrm{SO}_{4}$ plot, where the majority of ionic concentrations fall below the aquiline suggesting dissolution process of carbonates and silicates/sulphides. The samples in the plot tend to shift right due to the large excess $\mathrm{HCO}_{3}+\mathrm{SO}_{4}$ ions on the left of the plot because of reverse ion exchange and dominance of $\mathrm{Ca}+\mathrm{Mg}$ over $\mathrm{HCO}_{3}+\mathrm{SO}_{4}$ which suggests the interaction 

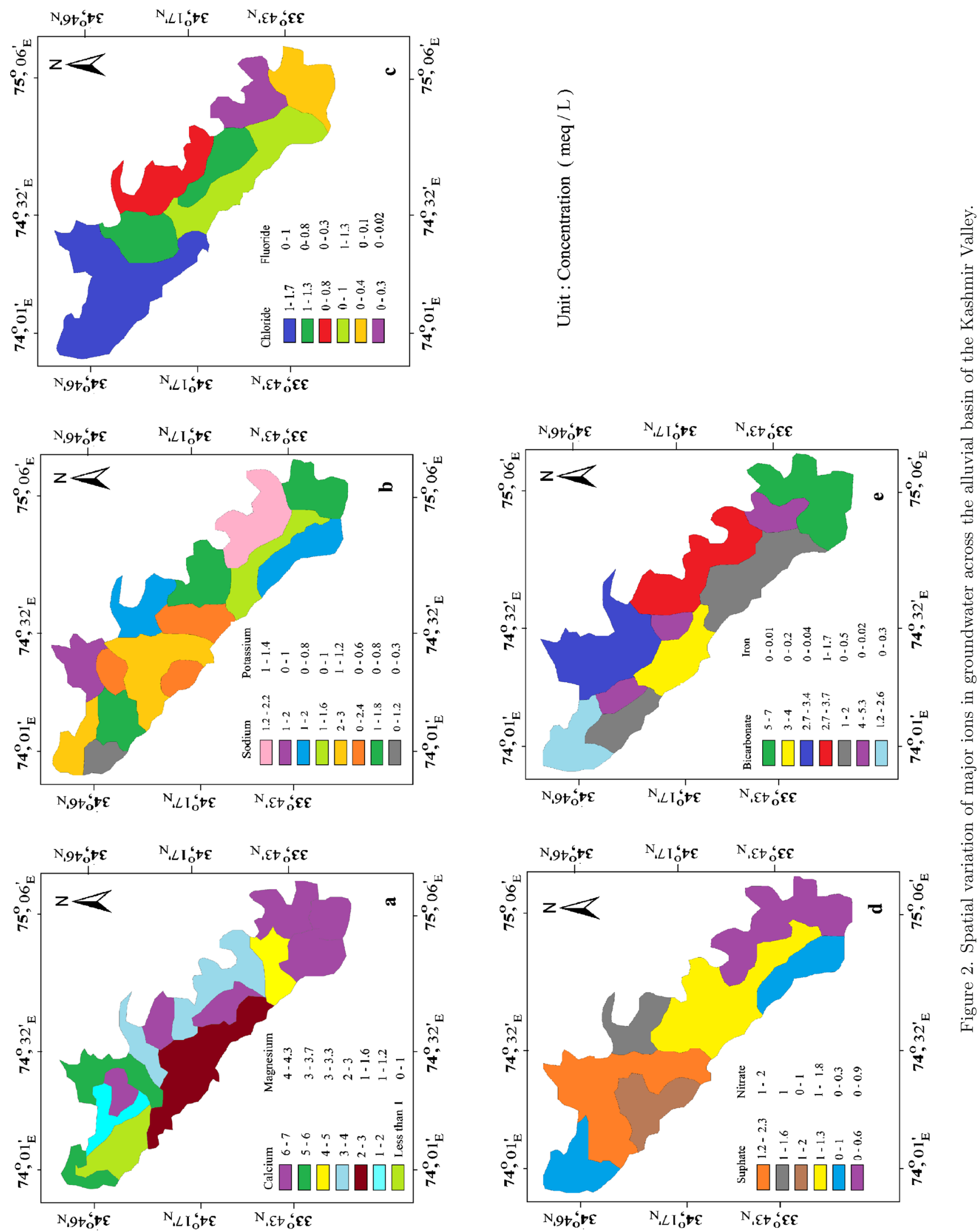
○ Shallow Groundw ater $\square$ Deep Groundwater
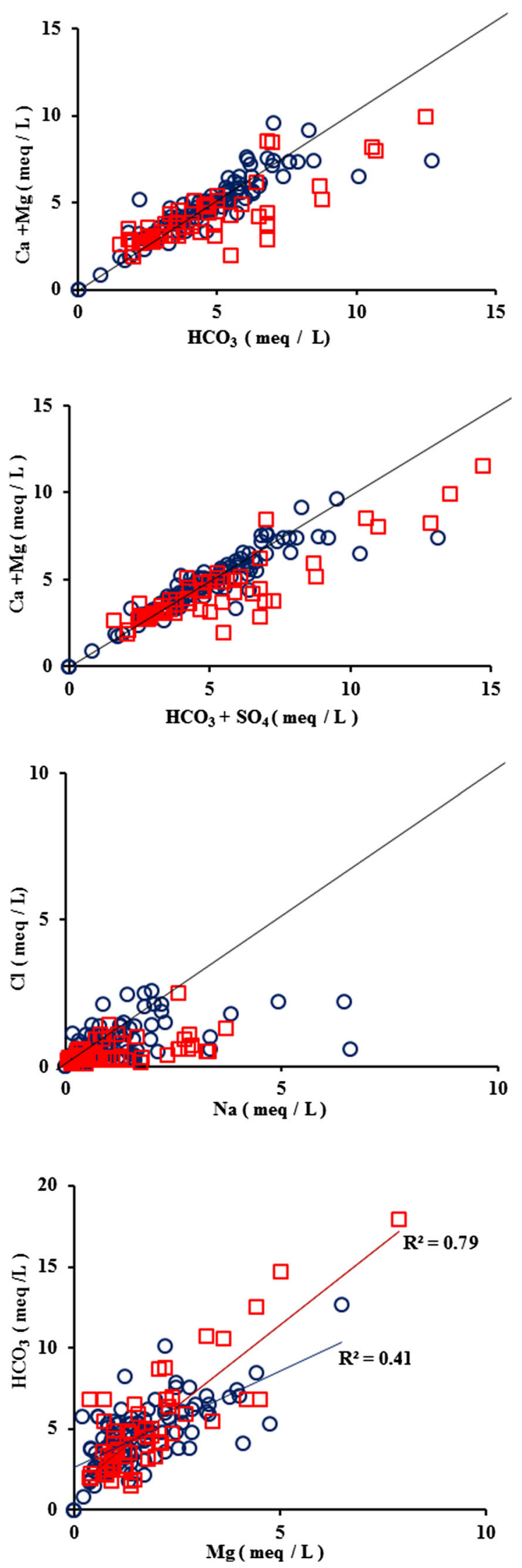

OSouthern $\square$ Central $\triangle$ Northern

a

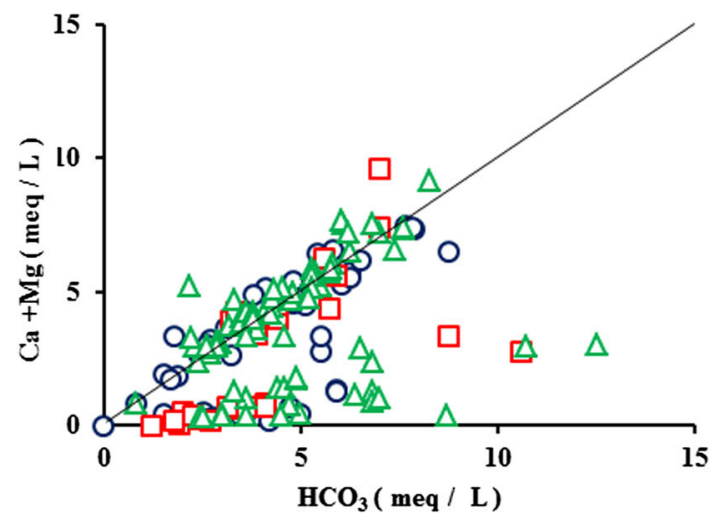

$b$

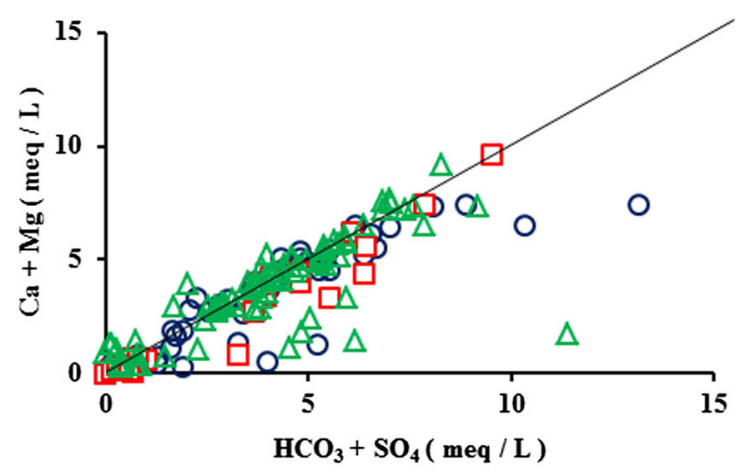

$\mathrm{c}$

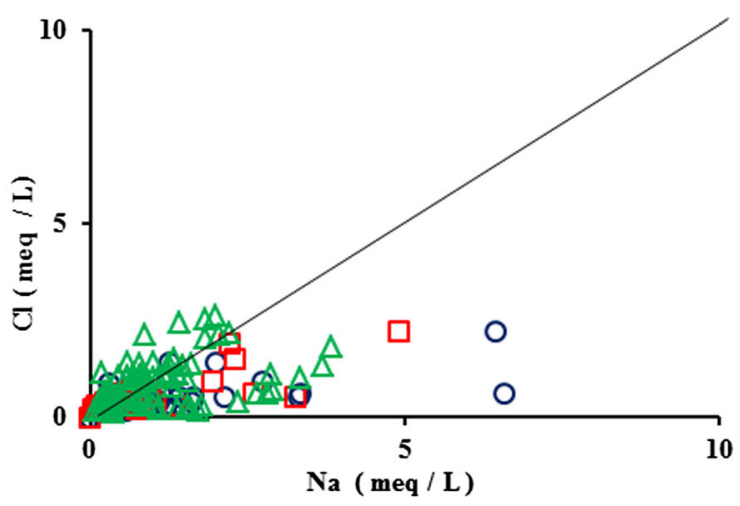

Figure 3. Scatter plots showing the sources of major ions in groundwater. 
of groundwater with both silicate and carbonate lithology during the movement from higher head to lower head.

The maximum points of south Kashmir fall on the aquiline of the plot $(\mathrm{Ca}+\mathrm{Mg})$ vs. $\mathrm{HCO}_{3}$ (figure 3a) indicating the carbonate lithology as the dominant source of major ions. This is also supported by the fact that south Kashmir is dominated by the carbonate lithology (Syringothyris Limestone and Triassic Limestone). However, many data points of northern and central Kashmir fall above the aquiline of plot $(\mathrm{Ca}+$ $\mathrm{Mg})$ vs. $\mathrm{HCO}_{3}$ and on the aquiline of plot $(\mathrm{Ca}+$ $\mathrm{Mg})$ vs. $\left(\mathrm{HCO}_{3}+\mathrm{SO}_{4}\right)$ (figure $3 \mathrm{~b}$ ) and $\mathrm{Na}$ vs. $\mathrm{Cl}$ (figure 3c) suggesting additional sources of major ions including silicates and/or evaporites. The good correlation of $\mathrm{Na} v s$. $\mathrm{Cl}$ may also be due to the contamination from domestic/municipal waste which is common in central and north Kashmir. The higher concentration of $\mathrm{Mg}, \mathrm{HCO}_{3}$ and $\mathrm{Fe}$ in groundwater in the central part is attributed to the ferro-magnesium minerals of the Panjal Volcanics and quarternary Karewa deposits which border the alluvial tract in this part of the valley.

\subsection{Depth to water table and flow direction}

The depth to groundwater is an important primary parameter, in determining the depth of material through which a contaminant/anthropogenic constituents must travel before reaching the aquifer. The depth to water level in the alluvial wells varies from $0-10 \mathrm{~m}$ below the ground. Out of 163 monitored wells, $69 \%$ of wells were classified as shallow with a water level of $0-2 \mathrm{~m}$ below ground level, while $6 \%$ of wells were classified as deeper with a water level of 3-7 m below ground level, in the alluvial basin of the valley. The depth to water table data and hydraulic gradient (figure 4) suggest that the groundwater flow in the area is largely controlled by the local surface topography (variation in elevation) as there is a general trend in groundwater levels from south to north of the valley besides a major river (river Jhelum) draining the whole Kashmir Basin and large water bodies (Wular lake, Dal lake, Nigeen lake, and Manasbal lake). The differences in the head produced by the topographic relief are the most significant driving force for groundwater flow in this region since the relief ranges from $0-1 \mathrm{~m}$ amsl within a span of $2 \mathrm{~km}$.

The most significant water level changes due to recharge in the valley occur during spring season when precipitation in the form of snow starts melting. There are several wells in the observation well network that showed water-level increase due to rapid groundwater recharge following significant precipitation events. These include observation wells near the Jhelum River which showed the response more quickly than wells farther away. All of these are relatively shallow wells with modest lengths of casing, drilled into unconfined aquifers. During the summer season people rely more on these wells because of diversion of surface water to the irrigation fields which results in more pumping of water from these wells, which later recover to their original levels during winter season due to heavy snow fall in the valley. Figure 4 shows the groundwater table map indicating that in general the flow occurs towards five directions, i.e., S-N, SW-NE, NE-W, SE-NW and SE-NE. Apart from this, the hydrogeochemical analysis of groundwater is considered useful not only in determining the chemistry of the groundwater, but also in understanding the movement of groundwater (Kumar et al. 2013). In the present study $\mathrm{Ca} / \mathrm{Mg}, \mathrm{SO}_{4} / \mathrm{Cl}$, $\mathrm{Na} / \mathrm{Cl}$ and $\mathrm{HCO}_{3} / \mathrm{Fe}$ ratios (refer figure 2) were used to determine the flow patterns in the alluvial basin of the valley. The $\mathrm{Ca} / \mathrm{Mg}$ ratio decreases from south to central part, which clearly shows the flow direction from south to north and southwest to northeast direction but on the other hand, the ratios of $\mathrm{SO}_{4} / \mathrm{Cl}$ increase towards the centre from both ends of the basin. The regions of high $\mathrm{Ca} / \mathrm{Mg}$ values coincide with the areas of low $\mathrm{SO}_{4} / \mathrm{Cl}$ values, which are the regions of high topography and regions of low $\mathrm{Ca} / \mathrm{Mg}$ values coincide with regions of high $\mathrm{SO}_{4} / \mathrm{Cl}$ values indicating the groundwater movement. However, $\mathrm{HCO}_{3} / \mathrm{Fe}$ ratios show that typical groundwater flow pattern of the basin, Fe ratios being high in central, is found in lower ratios towards northern and southern parts with a decreasing trend and increasing ratios of $\mathrm{HCO}_{3}$ determines the overall flow pattern of the basin from south to north and southwest to northeast. These flow patterns in the area not only modify the hydrogeochemical facies but also control their distribution in the basin.

\subsection{Hydrogeochemical facies}

Statistical distribution diagrams such as Piper Trilinear (Piper 1944) were used not only to gain better insight into the hydrochemical processes operating in the groundwater system but also for the purpose of characterizing the water types present in the area (figure 5). The $\mathrm{Ca}-\mathrm{HCO}_{3}, \mathrm{Mg}-$ $\mathrm{HCO}_{3}, \mathrm{Ca}-\mathrm{Mg}-\mathrm{HCO}_{3}$, and $\mathrm{Na}-\mathrm{HCO}_{3}$ being the most common hydrochemical facies, suggest that lithology and anthropogenic activities have played an important role in controlling the groundwater chemistry in the Kashmir Valley. The Ca$\mathrm{Mg}-\mathrm{HCO}_{3}$ water type is regarded as recharged 


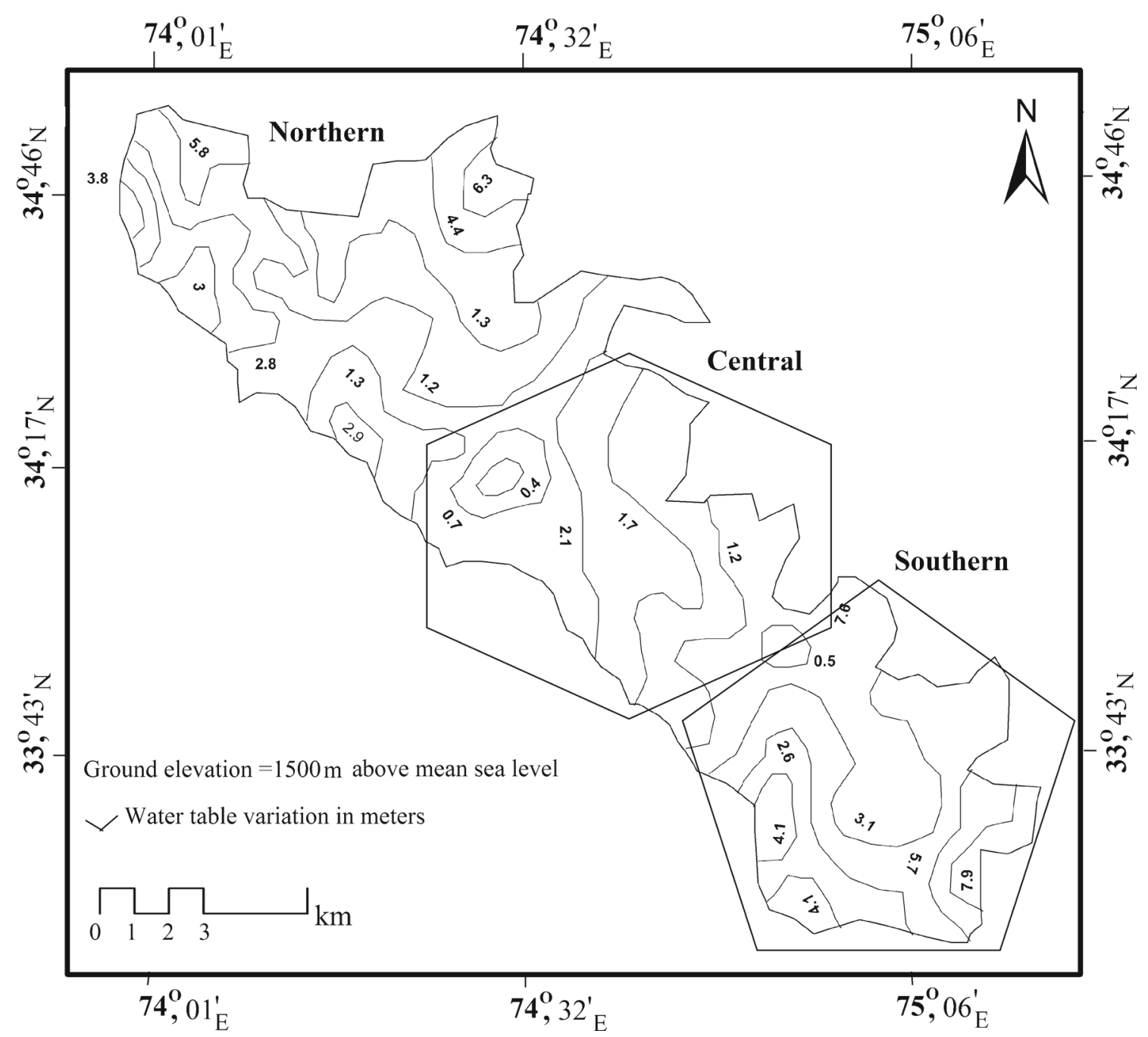

Figure 4. Map showing spatial variation of groundwater level in alluvial basin of Kashmir Valley.

water from sources related to atmospheric precipitation and dissolution of carbonates. This type of facies represents $80 \%$ of the southern, $95 \%$ central, and $90 \%$ of the northern areas of the valley. This phenomenon indicates that the hydrochemical properties as well as the factors affecting the hydrochemistry of these areas are similar. The $\mathrm{Na}-\mathrm{HCO}_{3}$ facies are present $20 \%$ in the southern, $5 \%$ in central and $10 \%$ in the northern area of the valley. This water type is a strong indicator of cation exchange process. The presence of excess sodium provided by clay minerals replacing the availability of calcium from the recharged $\mathrm{Ca}-\mathrm{Mg}-\mathrm{HCO}_{3}$ through the cation exchange reaction, in which $\mathrm{Ca}$ is retained in the aquifer material and $\mathrm{Na}$ is released to water, leads to the formation of $\mathrm{Na}-\mathrm{HCO}_{3}$ type of water. This was also confirmed by the indices of Base Exchange (CAI). From a geographical point of view, there is not much distinction between chemical properties of groundwater in north and central on one hand and south on the other hand, reflecting the effect of chemical processes occurring between the minerals within the lithologic framework and the groundwater movement.

\section{Groundwater quality assessment}

The suitability of water lies not in quantity but its intrinsic quality that makes water an important resource for sustainable development. Only economic advantage cannot sustain the practice. Other issues such as ecological and social issues need to be taken into account in the development and management of the schemes. Quality of water is part of the ecological issue required to be considered in the beginning (Nata et al. 2011). The quality of water is very important to mankind, because it is directly linked to human welfare. The analysed chemical parameters of groundwater play an important role in classifying and assessing 


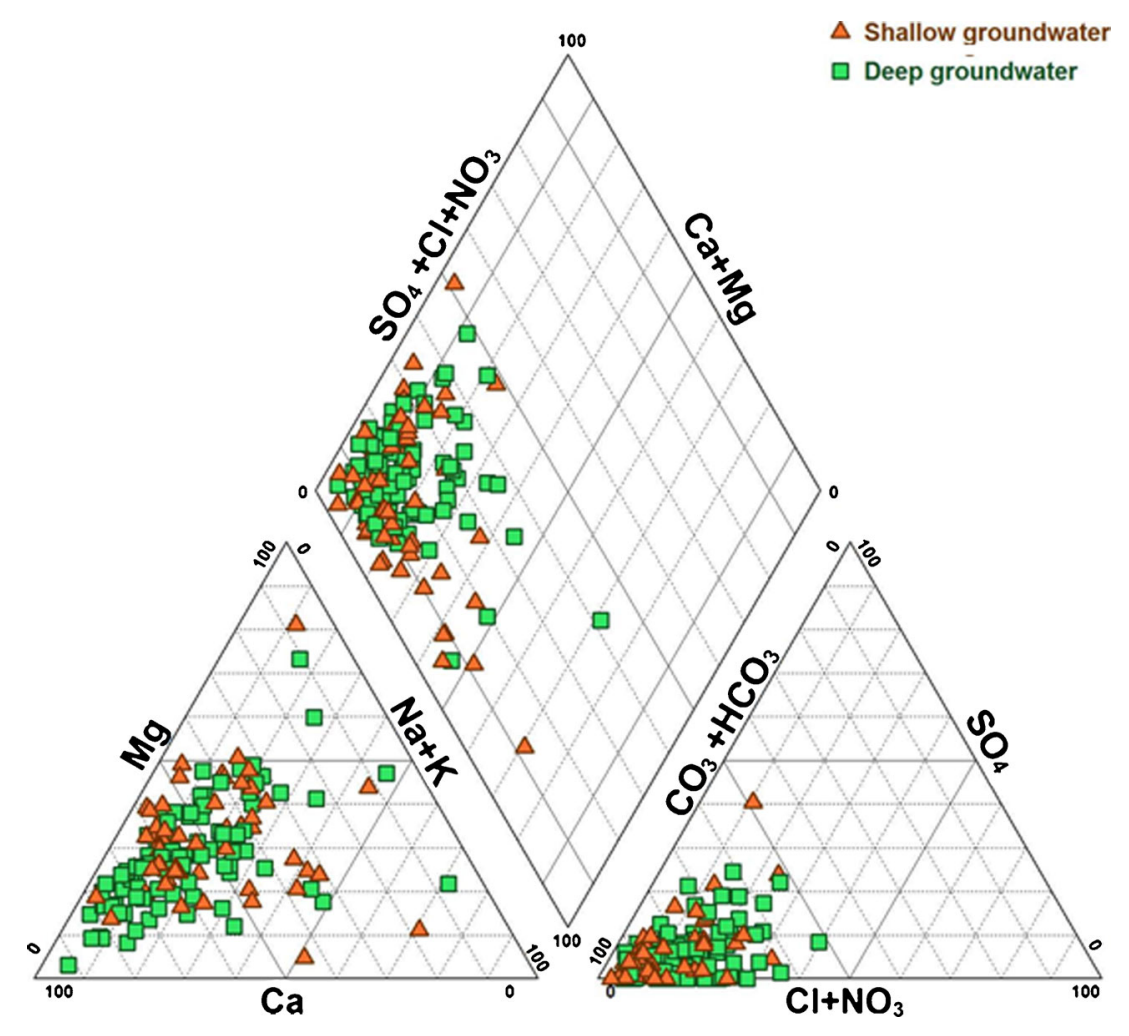

Figure 5. Piper trilinear plot and the hydrogeochemical facies in the Kashmir Valley.

water quality particularly with regard to its portable nature.

\subsection{Domestic purposes}

The concentrations of various ions in the groundwater were compared both with the specifications of World Health Organization (WHO 2006) and Indian standards (BISIS: 10500: 1991) for drinking water, where a majority of the samples from shallow and deep groundwater are within the permissible limits. The groundwater classification based on the hydrochemical properties and TDS for groundwater suitability, suggest that $65.68 \%$ from shallow groundwater and $69.49 \%$ from deep groundwater are below $<500 \mathrm{mg} / \mathrm{L}$ of TDS which is desirable for drinking purposes without any risk and $31.37 \%$ and $22 \%$ from deep groundwater and shallow groundwater are permissible for drinking (Davis and Dewiest 1966; Freeze and Cherry 1979).

\subsection{Livestock water quality}

Water for livestock should be of high quality to prevent them from various diseases, salt imbalance, or poisoning by toxic constituents. Most of the water quality variables for livestock are the same as for human drinking-water, although the total permissible levels of total suspended solids and salinity may be higher (Bhardwaj and Singh 2011). The total dissolved solids (TDS) is the main parameter usually used to evaluate the suitability of any water for livestock farming. Based on the Australian and UNESCO standards, the TDS value between zero and $2900 \mathrm{mg} / \mathrm{L}$ is suitable for all animals (Hamill and Bell 1986). In this case, the groundwater is good for livestock purposes as the TDS in groundwater ranged from 71.7-1495.4 mg/L.

\subsection{Groundwater for irrigation purposes}

Irrigation is one of the methods used to increase food production as it is directly linked to promoting economic growth and sustainable development of the Kashmir Valley. Groundwater as a source of water for irrigation would help the farmers in achieving maximum crop productivity; only then, when it can meet the quality criteria of WHO (2006) and BIS (1991) standards. Irrigation with poor quality waters may bring undesirable elements to the soil in excessive quantities affecting its fertility. To avoid this, suitability evaluation of groundwater becomes necessary. The following parameters were used to judge the suitability of water, sodium absorption ratio (SAR), residual sodium carbonate (RSC), United States Department of Agriculture (USDA) classification, Kelly index (KI), percentage sodium (\% Na), magnesium ratio (MR) and permeability index (PI). 


\subsubsection{Sodium absorption ratio (SAR)}

Sodium absorption ratio is an estimate of the degree to which sodium is be absorbed by the soil and is used to evaluate the water for irrigation. SAR has been calculated by using the formula SAR $=\mathrm{Na} / \sqrt{ }\left(\mathrm{Ca}^{2+}+\mathrm{Mg}^{2+}\right) / 2$ (Richards 1954). The present study reveals that all the samples (shallow groundwater $=100 \%$ and deep groundwater $=100 \%$ ) belong to sodium hazard class S1 which indicates that it is excellent for irrigation purposes.

\subsubsection{Residual sodium carbonate (RSC)}

According to USA Salinity Laboratory (1954) RSC value $<1.25 \mathrm{meq} / \mathrm{L}$ is safe; if the value varies between 1.25 and $2.25 \mathrm{meq} / \mathrm{L}$, it is of average quality and if more than $2.25 \mathrm{meq} / \mathrm{L}$ it is unsafe for irrigation. The following formula has been applied for $\mathrm{RSC}$ computation. $\mathrm{RSC}=\left(\mathrm{HCO}_{3}^{-}+\mathrm{CO}_{3}^{2-}\right)-$ $\left(\mathrm{Ca}^{2+}+\mathrm{Mg}^{2+}\right)$. The shallow groundwater and deep groundwater were analysed and the maximum number of samples (shallow groundwater $=97 \%$ and deep groundwater $=91 \%$ ) fall in the safe range and only few percent of samples from shallow groundwater $(2.64 \%)$ and deep groundwater $(8.33 \%)$ exceeds the rate of hazard, which reveals that they are not safe for irrigation.

\subsubsection{United States Department of Agricultural (USDA) classification}

According to this classification the $\mathrm{EC}<250 \mu \mathrm{S} / \mathrm{cm}$ is excellent ( $\mathrm{C} 1$ class), $250-750$ is good quality (C2 class), 750-2250 is of permissible (C3 class) and 2250-5000 unsuitable (C4 class) for irrigation purposes. The present observation suggests that suitability of groundwater lies between $\mathrm{C} 1$ and $\mathrm{C} 2$ class as the TDS of the groundwater ranges from 71.7 to $1495 \mu \mathrm{S} / \mathrm{cm}$ which means that the present status of groundwater in the Kashmir Valley is good for irrigation purposes.

\subsubsection{Kelly index (KI)}

Kelley (1940) and Paliwal (1967) introduced an important parameter for evaluating quality criteria for water for irrigation purposes by using the following formula, $\mathrm{Na}^{+} / \mathrm{Ca}^{2+}+\mathrm{Mg}^{2+}$. The KI values computed for the study area ranged from shallow groundwater $=0.04-0.9 \mathrm{meq} / \mathrm{L}$ and deep groundwater $0.035-1.0 \mathrm{meq} / \mathrm{L}$ with mean of 0.2 and $0.27 \mathrm{meq} / \mathrm{L}$, respectively. All the values fall within the normal range (1), which suggests that groundwater is suitable for irrigational practice.

\subsubsection{Percentage sodium (\% $\mathrm{Na}$ )}

Sodium is an important ion used for the classification of irrigation water. Its reaction with soil reduces soil permeability (Hakim et al. 2009; Vasanthavigar et al. 2010). The sodium in irrigation water is usually expressed in \% Na (Tank and Chandel 2010) expressed as, $\mathrm{Na} \%=\mathrm{Na}^{+}+\mathrm{K}^{+} /$ $\left(\mathrm{Ca}^{2+}+\mathrm{Mg}^{2+}+\mathrm{K}^{+}+\mathrm{Na}^{+}\right) 100$. The present study suggests that groundwater is good for irrigation purposes as majority of samples fall in the range of shallow groundwater $=2.32-13.3 \%$ and deep groundwater $=0.53-11.09$ with an average of 7.3 and $6.2 \%$, respectively, which indicates the groundwater in the Kashmir Valley is good for irrigation purposes.

\subsubsection{Magnesium absorption ratio (MAR)}

Magnesium hazard ratio was proposed by Szabolcs and Darab (1964). Paliwal (1972) developed an index for calculating the magnesium hazard (MR) by using the formula, MAR $=\left[\mathrm{Mg}^{2+} /\left(\mathrm{Ca}^{2+}+\right.\right.$ $\left.\mathrm{Mg}^{2+}\right) 100$. MAR value exceeding $50 \%$ is harmful and unsuitable for irrigation use. In the present study, the majority (94\%) of samples fall under this range and $6 \%$ of samples exceed this limit. The excessive magnesium in these samples is due to influence of Dolomitic limestone in these areas (Malingpur, Bandipur, Sopore), which suggests that groundwater in the Kashmir Valley is good for agricultural purposes.

\subsubsection{Permeability index (PI)}

Doneen (1964) evolved a criterion for evaluating the suitability of water for irrigation based on PI. According to this classification, Class I and II possessing maximum permeability $>75 \%$ are classified as good for irrigation while third category (Class III) having $25 \%$ maximum permeability are considered unsuitable for irrigation purposes (Nagaraju et al. 2006). PI is calculated using the following equation: $\mathrm{PI}=\left(\mathrm{Na}^{+}+\mathrm{HCO}_{3}^{-}\right) /\left(\mathrm{Ca}^{2+}+\mathrm{Mg}^{2+}+\right.$ $\left.\mathrm{Na}^{+}\right) 100$. The PI values computed ranged from $57-$ $128.35 \%$ in case of shallow with a mean of $96 \%$ groundwater and $72-138 \%$ with an average of $98 \%$ in deep groundwater, respectively. The study suggested that groundwater in the study area falls under class I and II, and hence is considered good for irrigation.

\section{Conclusion}

The groundwater in the Kashmir Valley, India is generally alkaline having permissible limit of an electrical conductivity. $\mathrm{Ca}^{2+}$ was the dominant 
cation and $\mathrm{HCO}_{3}^{-}$was dominant anion in groundwater. The order of abundance of cations was $\mathrm{Ca}^{2+}>\mathrm{Mg}^{2+}>\mathrm{Na}^{+}>\mathrm{K}^{+}$and in anions the order follows $\mathrm{HCO}_{3}^{-}>\mathrm{SO}_{4}^{-}>\mathrm{Cl}^{-}>\mathrm{NO}_{3}^{-}$. The average concentrations of various chemical parameters were found to be higher in shallow aquifer than in deeper aquifer. High concentration of $\mathrm{HCO}_{3}$ and $\mathrm{pH}$ less than 8.8 clearly indicated intense chemical weathering processes have taken place in the study area. Four types of groundwater were found in the valley as: $\mathrm{Ca}-\mathrm{HCO}_{3}, \mathrm{Mg}-\mathrm{HCO}_{3}, \mathrm{Ca}-\mathrm{Mg}-\mathrm{HCO}_{3}$ and $\mathrm{Na}-\mathrm{HCO}_{3}$. The study suggested that the groundwater flow in the study area is largely controlled by the local surface topography (variation in elevation) as there is a general trend in groundwater levels from south to north of the valley. The flow patterns not only modify the facies but also control the distribution. The concentrations of various ions in the groundwater were compared both with the specifications of World Health Organization (WHO 2006) and Indian standards (BISIS: 10500: 1991) for its suitability, which suggested that groundwater in the valley is good for all purposes (i.e., domestic, livestock, and irrigation). The groundwater quality analyses indicate that the host lithology plays a dominant role in controlling the groundwater chemistry and the carbonate dissolution process may be the dominant source of major ions followed by silicate weathering and ion-exchange processes in the Kashmir Valley.

\section{Acknowledgements}

The authors express gratitude to the anonymous reviewers whose comments and suggestions improved the quality of this manuscript.

\section{References}

Agarwal D P, Kusumgar V V and Radhakrishnan-Murthy C 1979 Chronostratigraphy of loessic and lacustrine sediments in the Kashmir Valley, India; Acta Gool. Acad. Sci. Hungarica 22 185-196.

APHA, AWWA, WEF 2001 Standard methods for the examination of water and waste water (APHA-AWWA-WEF Washington).

Apodaca L E, Jeffrey B B and Michelle C S 2002 Water quality in shallow alluvial aquifers, Upper Colorado River Basin, Colorado, 1997; J. Am. Water Res. Assoc. 38(1) 133-143.

Bhardwaj V and Singh D S 2011 Surface and groundwater quality characterization of Deoria District, Ganga Plain, India; J. Environ. Earth Sci. 63 383-395, doi: $10.1007 /$ s12665-010-0709-x.

Bhardwaj V, Singh D S and Singh A K 2010 Hydrogeochemistry of groundwater and anthropogenic control over dolomitization reactions on alluvial sediments of the Deoria district-Ganga plain, India; Environ. Earth Sci. 59 1099-1109, doi: 10.1007/ s12665-009-0100-y.
Bhalme S P and Nagarnaik P B 2012 Analysis of drinking water of different places: A review; Int. J. Eng. Res. Appl. 2 3155-3158.

BIS 1991 Specifications for drinking water, IS:10500:1991, Bureau of Indian Standards, New Delhi.

Davis S N and Dewiest R J M 1966 Hydrogeology; Wiley, New York, Current Trends in Geol. 6463.

Dawson P A 2013 Role of sulphate in development; Mater Research, Translational Research Institute, Woolloongabba QLD, Australia, page 1 of 24. Reproduction Advance Publication REP-13-0056.

Doneen I D 1964 Notes on water quality in agriculture; Water Science and Engineering, Paper 4001. Department of Water Sciences and Engineering, University of California.

Ewusi A, Obiri-yeboah S, Voigt H and Stephen 2013 Groundwater quality assessment for drinking and irrigation purposes in Obuasi Municipality of Ghana: A preliminary study; J. Environ. Earth Sci. 5(1) 6-17.

Freeze R A and Cherry J A 1979 Groundwater; Prentice Hall, New Jersey.

Gibbs R J 1970 Mechanisms controlling world water chemistry; Science $\mathbf{1 7 0}$ 795-840.

GSI 1977 Geology and mineral resources of states of India. Part X: Jammu and Kashmir State; Geol. Surv. India 30 $1-70$.

Gundogdu K S and Guney I 2007 Spatial analyses of groundwater levels using universal Kriging; J. Earth Syst. Sci. 116(1) 49-55.

Gunj J L and Khar B M 1984 Tectonics and hydrocarbon prospects of Kashmir Valley - possible exploratory targets; Petrol. Asia J. 7(1) 207-217.

Hakim M A, Juraimi A S, Begum M, Hasanuzzaman M, Uddin M K and Islam M M 2009 Suitability evaluation of groundwater for irrigation, drinking, and industrial purposes; Am. J. Environ. Sci. 5(3) 413-419.

Hamill L and Bell F G 1986 Groundwater resource development and management; The University Press, Cambridge, Great Britain, 34p.

Ifatimehin O O and Musa S D 2008 The prospects of sustainable management of domestic water supply and sanitation in Kogi strata; J. Environ. Policy Issues 41812.

Ishaku J M 2011 Assessment of groundwater quality index for Jimeta-Yola area, northeastern Nigeria; J. Geol. Mining Res. 3(9) 219-231.

Jeelani G 2005 Chemical quality of the spring waters of Anantnag, Kashmir; J. Geol. Soc. India 66 453462.

Jeelani G 2007 Hydrogeology of hard rock aquifer in Kashmir Valley: Complexities and uncertainties; In: Groundwater dynamics in hard rock aquifers - including sustainable management and optimal monitoring network design (eds) Ahmed S, Jayakumar R and Abdin S (Netherland: Springer-Verlag), 265p.

Jeelani G and Shah A Q 2006 Geochemical characteristics of water and sediment from the Dal Lake, Kashmir Himalaya, India: Constraints on weathering and anthropogenic activity; Environ. Geol. 50 12-23.

Jeelani G et al. 2011 Geochemical characterization of surface water and spring water in SE Kashmir Valley, western Himalaya: Implications to water-rock interaction; J. Earth Syst. Sci. 120(5) 921-932.

Jehangir A et al. 2011 Geochemistry and irrigation quality of groundwater along river Jhelum in south Kashmir, India; Recent Res. Sci. Technol. 3(6) 5763.

Kalpana L and Elango L 2013 Assessment of groundwater quality for drinking and irrigation purposes in Pambar river sub-basin, Tamil Nadu; Indian J. Environ. Protection 33(1) 1-8. 
Kelley W P 1940 Permissible composition and concentration of irrigation water; Proc. Am. Soc. Civil Eng. 66 607-613.

Kuchel O, Buce N T, Racz K, Deheam A, Serri O and Kyncl J 1986 Role of sulfate conjugation of catecholamines in blood pressure regulation; Fed. Proc. 45 2254-2259.

Kumar S K, Rammohan V, Sahayam J D and Jeevanandam M 2008 Assessment of groundwater quality and hydrogeochemistry of Manimuktha River basin, Tamil Nadu, India; Environ. Monit. Assess., doi: 10.1007/s10661-008-0633-7.

Kumar P S J, Elango L and James E J 2013 Assessment of hydrochemistry and groundwater quality in the coastal area of south Chennai, India; Arabian J. Geosci., doi: 10.1007/s 12517-013-0940-3.

Li P Y, Qian H, Wu J H and Ding J 2010 Hydrochemical formation mechanisms and quality assessment of groundwater with improved TOPSIS, method in Pengyang County, northwest China; E-J. Chem. 8(3) 1164-1173, http:// www.e-journals.net2011.

Martinez D E and Bocanegra E M 2002 Hydrogeochemistry and cation exchange processes in the coastal aquifer of Mar Del Plata, Argentina; Hydrogeol. J. 10 393-408.

Meybeck M 1987 Global chemical weathering of surficial rocks estimated from river dissolved loads; AMJ Sci. $\mathbf{2 8 7}$ 401-428.

Middlemiss C S 1910 Revision of Silurian-Trias sequence of Kashmir; Rec. Geol. Surv. India 40 206-260.

Middlemiss C S 1911 Sections in the Pir Panjal range and Sindh Valley, Kashmir; Rec. Geol. Surv. India 41 115-144.

Mitra B K, Sasaki K, Enari N, Matsuyama and Fujita M 2007 Suitability assessment of shallow groundwater for agriculture in sand dune area of northwest Honshu Island, Japan; Appl. Ecol. Environ. Res. 5(1) 177-188.

Nagaraju A, Suresh S, Killham K and Hudson-Edwards K 2006 Hydrogeochemistry of waters of Mangampeta Barite mining area, Cuddapah Basin, Andhra Pradesh, India; Turkish J. Eng. Environ. Sci. 30 203-219.

Nata T, Abraham B, Bheemalingeswara K and Tesfamichael G 2011 Suitability of groundwater quality for irrigation with reference to hand dug Wells, Hantebet Catchment, Tigray, Northern Ethiopia; MEJS 3(2) 31-47.

Paliwal K V 1967 Effect of gypsum application on quality of irrigation waters; The Madras Agricultural J. 59 646-647.

Paliwal K V 1972 Irrigation with saline water; Monogram no. 2 (New series), New Delhi, IARI, 198.

Piper A M 1944 A graphical interpretation of water analysis; Trans. Am. Geophys. Union 25 914-928.
Rajmohan N, Elango L, Ramachandran S and Natarajan M 2000 Major ion correlation in groundwater of Kancheepuram region, south India; Indian J. Environ. Protection 20(3) 188-193.

Richards L A 1954 Diagnosis and improvement of saline and alkali soils, Agricultural Handbook 60, US Dept. Agric., Washington DC.

Sarin M M, Krishnaswamy S, Dilli K, Somayajulu B L K and Moore W S 1989 Major ion chemistry of the GangaBrahmaputra river system: Weathering processes and fluxes to the Bay of Bengal; Geochim. Cosmochim. Acta 53 997-1009.

Schoeller H 1977 Geochemistry of groundwater; In: Groundwater Studies; An Int. Guide for Research and Practice, UNESCO, Paris, Ch. 15, pp. 1-18.

Singh A K and Hasnain S J 1998 Major ion chemistry and weathering control in high altitude basin: Alaknanda River, Garhwal Himalaya, India; Hydrological Science-des Sciences Hydrologiques 43(6) 825-843.

Singh A K and Hasnain S J 2002 Aspects of weathering and solute acquisition processes controlling chemistry of sub-alpine proglacial streams of Garhwal Himalaya, India; Hydrol. Processes 16 835-849.

Subba Rao N 2008 Factors controlling the salinity in groundwater in parts of Guntur district Andhra Pradesh, India; Environ. Monit. Assess. 138 327-341.

Szabolcs and Drab 1964 The influence of irrigation water of high sodium carbonate content soils; Proceeding of 8th ISSS Trans. 1 802-812.

Tank D K and Chandel C P S 2010 Analysis of the major ion constituents in groundwater of Jaipur city; Nature Sci. 8(10) $1-7$.

US Salinity Laboratory 1954 Diagnosis and improvement of saline and alkali soils; U.S.G.P.O., Washington, $160 \mathrm{p}$.

UNESCO 2000 Groundwater pollution; International Hydrological Programme.

Vasanthavigar M, Srinivasamoorthy K, Rajiv Gantha R, Vijayaraghavan K and Sarma V S 2010 Characterization and quality assessment of groundwater with special emphasis on irrigation utility: Thirumanimuttar subbasin, Tamil Nadu, India; Arab, Geosci. J., doi: 10.1007/ s12517-010-0190-6.

Wadia D N 1975 Geology of India (Tata McGraw Hill: New Delhi), 560p.

WHO 2006 Guidelines for drinking water quality; First addendum to 3rd edn, Recommendation. Geneva, 595p. 